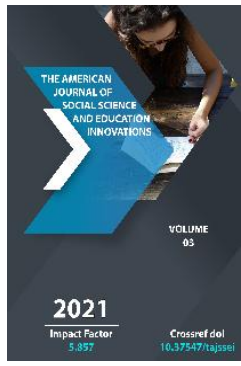

Journal Website: http://theamericanjour nals.com/index.php/taj ssei

Copyright: Original content from this work may be used under the terms of the creative commons attributes 4.0 licence.

\section{Landscape Anomaly As An Object Of Geoindication Research}

\author{
Olimjon Isomiddinovich Abduganiev \\ Candidate Of Geographical Sciences, Associate Professor, Fergana State University, \\ Uzbekistan
}

Munira Ibrohimjon Kizi Jarkinova

Master Of Geography, Fergana State University, Uzbekistan

Zilola Kahharjon Kizi Shermatova

Master Of Geography, Fergana State University, Uzbekistan

\title{
ABSTRACT
}

The article describes the methods and research stages of landscape-indicative surveys to identify landscape anomalies. Also, the landscape abnormalities associated with tectonic structures are indicated.

\section{KEYWORDS}

Indication, landscape anomaly, oil and gas bearing structures, aerial photograph.

\section{INTRODUCTION}

Landscape indication is widely used in soil and geological surveys, mineral exploration, hydrogeological and engineering-geological research. The landscape-indication method includes the solution of the following tasks: first, the identification of landscape anomalies and, secondly, their interpretation in order to establish the causes of anomalies and the selection of indicators associated with tectonic structures among them. Nowadays, the basics of landscape mapping have been sufficiently developed, in the course of which primitive natural territorial complex (PTC) of various ranks are distinguished [3].Landscape indication determines, first of all, geological, hydrogeological, hydrological, soil and climatic conditions, as well as the consequences of human activity on the external appearance of the landscape, its individual components. Landscapes, tracts, facies, their most physiognomic components (relief, vegetation, soils, reservoirs, etc.), stable combinations of components, anthropogenic elements of the terrain structure are used as indicators.

For the purpose of searching for activated $\urcorner$ neotectonic structures, there arises the practical need to isolate anomalous physiognomic combinations of components of the PTC, differing in qualitative and quantitative values from similar components 
of neighboring areas. The physiognomic appearance typical for any indicator of the landscape is considered as a background [1]. Morphological, genetic and age features of the landscape and landscape-forming processes of the local area, which distinguish this area from the surrounding background and contrast with it, are considered to be a landscape anomaly. Obviously, landscape anomalies cannot be viewed outside the background on which they exist. Thus, the study of the landscape in most cases rests on the problem of space-time connections "typically-atypical." The concepts of "landscape anomaly" and "background" serve to differentiate the territory according to the appearance, shape, quantity and other features of the manifestation of a particular "quality" of the landscape.

\section{MATERILS AND METHODS}

Features of the landscape, giving the basis for the selection of anomalies, causally caused by the existing structural and physiographic conditions, these features are natural, typical for this area. They are anomalous only because they indicate a deviation from the "standard", the most common conditions, indicators, characteristics of the landscape. The term "landscape anomaly" is not strictly synonymous with any PTC of a certain rank. Geoindication studies are important to identify anomalies of tectonic origin. To the landscape anomalies of tectonic origin, we include such parts of the territory, the physiognomic features of the landscape which differ from the background and are associated with the local influence of endogenous factors.

Local effects of endogenous factors causing the emergence of a landscape anomaly can be either passive, manifested through selective denudation of rocks of heterogeneous strength, or active if they are caused by the manifestation of differentiated tectonic movements - the formation and activation of local structural forms, including discontinuous disturbances [1].

According to the indicative features of the manifestation in the landscape, landscape anomalies can be divided into areal and linear. Reflecting the morphology of plicative structural forms, areal anomalies have a different shape. Linear landscape anomalies are most often associated with faults. Under the influence of changes in the tectonic regime of the territory, the speed and nature of the processes of relief formation both change and, accordingly, their manifestation in the landscape also changes. Analysis of the relief of the watershed spaces and the structure of river valleys, carried out on aerial surveys, has independent significance in identifying folded structures in the search for minerals $[4,5]$.

\section{RESULTS AND DISCUSSION}

After that, continuous indicator interpretation was made on the basis of interpretation signs, which were established as a result of a comprehensive comparison of the studied airborne materials with topographic, geological, geomorphological, soil, geobotanical, hydrogeological and landscape maps over the territory. Its essence lies in the division of territory into typical landscapes and the allocation on their background of anomalous areas that differ in physiognomic features. In special indicator studies in the Fergana Valley are presented in the works of I. Abduganiev (1976), he used geological, geomorphological, geobotanical and soil data, on the basis of which a preliminary indication scheme was compiled with fragmented information of varying degrees of detail [2].

Vegetation, using its species, can be used as an indicator of the environment. Depending on the indication object, groups of plants are identified - indicators of soil, climate, bedrock, etc. When interpreting soils, they can also perform indicator qualities such as: the 
relationship with the parent rock, the effect of which affects the color of the soil, the mechanical composition, the nature of the soil skeleton, soil thickness and their individual horizons, humidity and chemism [4].

When working with aerial photographs for the purpose of preliminary decryption, priority is given to a set of features related to the landscape features of areas of known petroleum structures. Similar landscape features are then sought within the study area. Here, a significant help is provided by comparison with the interpreted neighboring areas, which have similar geological and physiographic conditions.

The result of the preparatory stage consists in the division of the territory into landscapes, highlighting anomalous plots on their background that differ in physiognomic features. After all the anomalous features of landscapes are identified for the investigated area by the above mentioned method, the field phase of work begins, consisting in visiting each of them and identifying the conditions to which it is timed.

To identify landscape indicators in the field, key areas are selected that characterize the main facies, tracts or landscapes that are subject to indicator research. In the process of studying key areas, the usual methods of the indicator method are used: reference or detailed route description of landscapes, landscape profiling, combined with the extensive use of aerophotomaterials. Analysis of landscape profiles and descriptions of key areas allows you to: check the applicability of the preliminary indication scheme; clarify it and fill up with some missing information about the connection of natural complexes with certain geological and tectonic conditions; to identify the characteristic features of the image of the landscape in aerial photographs [2].
After completion of the field work, the final detailed continuous interpretation of aerial photographs is carried out, the main tasks of which are to summarize the field material for identifying landscape indicators of oil and gas bearing structures; extrapolation of installed landscape indicators to the entire work area; compilation of the final summary of interpretation signs of geological objects of the studied territory. The use of indicator cards is determined by the demands of practice. Most often, they are currently in demand for land reclamation, engineering-geological, soil forest typological studies. For administrative regions where the population of the territory exceeds 50\%, landscape maps can significantly simplify the geological large-scale survey of the territory. For the calculated coefficients of the relative and absolute tension of the territory [5].

After the completion of field and office research, a comprehensive interpretation of the results obtained and the compilation of text and cartographic documents are carried out. Approximate predictive assessment of the presence of tectonic structures in the study area according to landscape indicators is carried out using indicator tables (schemes) and maps compiled on the basis of verified data on the timing of landscape indicators to certain geological and tectonic conditions.

Relief is the main indicator of the manifestations of tectonic movements of the earth's crust. The relief is directly observed on aerial photographs in all the variety of its forms. The origin of the river valley is closely related to the tectonic structure, tectonic movements of the earth's crust, the slope of the earth's surface, resistance to erosion of rocks and climate change. The study of terraces is of great importance, since they characterize the stages of development of river valleys, cycles of tectonic movements.

\section{CONCLUSION}


The landscape-indicative map, the main final document of indicator studies, shows the severity of local structures in various landscapes. Legends of indicator maps are usually divided into two parts: landscape, reflecting the genetic groups of natural complexes, and indicator, showing various indicators of local uplifts and faults. In contrast to ordinary landscape maps, on the map in question, the landscape load must be focused, sometimes to some extent generalized, in order to better reflect the influence of the newest structures on the formation of the modern landscape.

Thus, the whole complex of cameral and field landscape-indicator studies on the search for tectonic structures consists of a series of sequentially performed and mutually complementary stages of work, of which a very significant role is played by the prefield indicator interpretation of aerial photographs. The concentration of field work in key areas and the widespread use of aerial methods in the distribution (extrapolation) of indication signs to the entire survey area increase efficiency.

\section{REFERENCES}

1. Abdufaniev I, Abdufaniev O. Features of the use of the landscape-indicator method when searching for oil and gas structures. "Geographical Society of Uzbekistan" 26-volume, Toshkent. 2006. 28-29 p.

2. Kleschenkov A.V. On the issue of indication of slow-flowing geodynamic processes by a complex of parameters. // Geologists of the XXI Century: Proceedings of the IX All-Russian Scientific Conference of Students, Postgraduates, and Young Specialists (Saratov, April 2-4, 2008). - Saratov: Publishing House of SO EAGO, 2008. - p. 128-130.

3. Obukhovsky Yu.M. Landscape indication. Minsk, 2008.
4. Gomzyakov A.V. Geomorphology with the basics of geology: study guide / A.V. Gomzyakov, M.S. Zakharov. - St. Petersburg: NOIR Saint-Petersburg, 2014. $-188 \mathrm{p}$.

5. Abduganiev O.I., Turdiboyeva Sh.. Estimation of ecological-economic condition of territories (on the example of Ferghana regions). Международный научно-практический журнал «Экономика и социум» № 9 (64), 2019. Б. 371-378. 